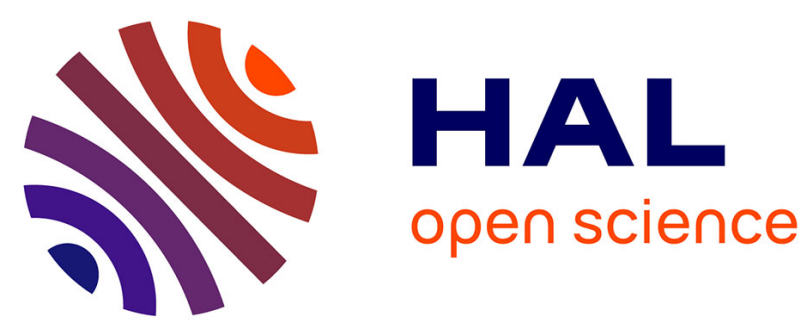

\title{
Following the mechanisms of a single water droplet drying by means of photonic resonant structure
}

Lucas Garnier, Hervé Lhermite, Véronique Vié, Hervé Cormerais, Octave Pin, Quentin Liddell, Jean-Charles Potier, Bruno Bêche

\section{- To cite this version: \\ Lucas Garnier, Hervé Lhermite, Véronique Vié, Hervé Cormerais, Octave Pin, et al.. Following the mechanisms of a single water droplet drying by means of photonic resonant structure. CLEO Europe - EQEC, Jun 2019, Munich, Germany. hal-01993145v2}

\section{HAL Id: hal-01993145 \\ https://hal.science/hal-01993145v2}

Submitted on 5 Jun 2019

HAL is a multi-disciplinary open access archive for the deposit and dissemination of scientific research documents, whether they are published or not. The documents may come from teaching and research institutions in France or abroad, or from public or private research centers.
L'archive ouverte pluridisciplinaire HAL, est destinée au dépôt et à la diffusion de documents scientifiques de niveau recherche, publiés ou non, émanant des établissements d'enseignement et de recherche français ou étrangers, des laboratoires publics ou privés. 


\title{
Following the mechanisms of a single water droplet drying by means of photonic resonant structure
}

\author{
Lucas Garnier ${ }^{1}$, Hervé Lhermite ${ }^{2}$, Véronique Vié ${ }^{1}$, Hervé Cormerais ${ }^{2,3}$, \\ Octave Pin ${ }^{3}$, Quentin Liddell ${ }^{3}$, Jean-Charles Potier ${ }^{1}$, Bruno Bêche $^{1}$ \\ 1. Université Rennes 1, CNRS, Institut de Physique de Rennes - UMR 6251, F-35000 Rennes, France \\ 2. Université Rennes 1, CNRS, Institut d'Electronique et de Télécommunication de Rennes, UMR 6164, 35042 Rennes, France \\ 3. CentraleSupelec, Campus de Rennes, 35510 Cesson-Sévigné, France \\ E-mail : lucas.garnier@univ-rennes1.fr (L. Garnier); bruno.beche@univ-rennes1.fr (B. Bêche). \\ https://ipr.univ-rennes1.fr/interlocuteurs/bruno-beche
}

We have designed and fabricated integrated photonic micro-resonators (MRs) devices in polymer UV210 on a $\mathrm{SiO}_{2}$ substrate. UV210 is a positive resin that features an absorption band in the deep-UV domain. Such a property allows us to perform photolithography at lower wavelength than the traditional i-line photolithography so as to design smaller and more precise structures [1]. By using such MR as sensor [2,3], we have monitored the evaporation of a sessile water droplet by dynamically tracking its optical transduced signal. To do so, a broadband laser $(\lambda=790 \mathrm{~nm}, \mathrm{FWHM}=40 \mathrm{~nm})$ is coupled to a set of MRs through the injection in a tapered access waveguide. The use of a broadband laser allows us to visualize several resonances on the same spectrum, which increases the precision of the data treatment. The water droplet is deposited on the MRs and the transduced signal is acquired during the whole drying process. The output optical signal is monitored by the mean of an optical spectrum analyser with a frequency of acquisition of about $1 \mathrm{~Hz}$. The collected data are treated by a computation software, which aims at extracting the free spectral range (FSR) of the resonant mode present in the MR. The FSR is related to the opto-geometrical characteristics of the structure through the formula $F S R=\frac{\lambda^{2}}{P . n_{e f f}^{g p e}}$, where $\lambda$ is the wavelength, $P$ the geometrical perimeter of the resonator, and $n_{\text {eff }}^{g p e}$ the group effective index of the mode. As $n_{e f f}^{g p e}$ is influenced by the optical index of the surrounding of the resonator, the drying process leaves a signature on the FSR dynamics (Fig.1 (a)). This signature corresponds to a generic shape of the curve $F S R=f(t)$, which can be sliced in three zones (see Fig.1 (b)).

(a)

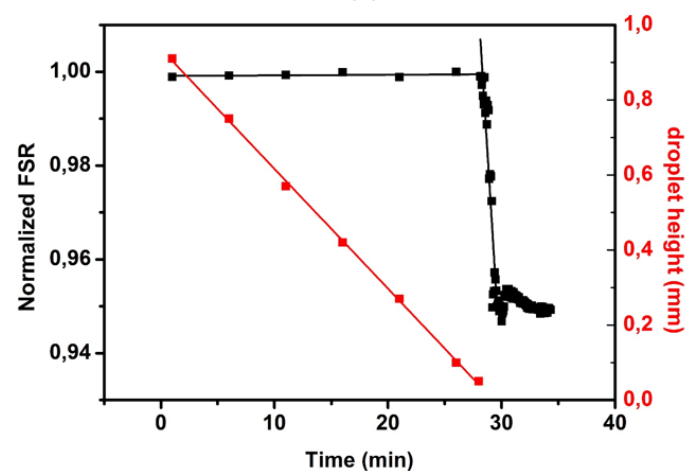

(b)

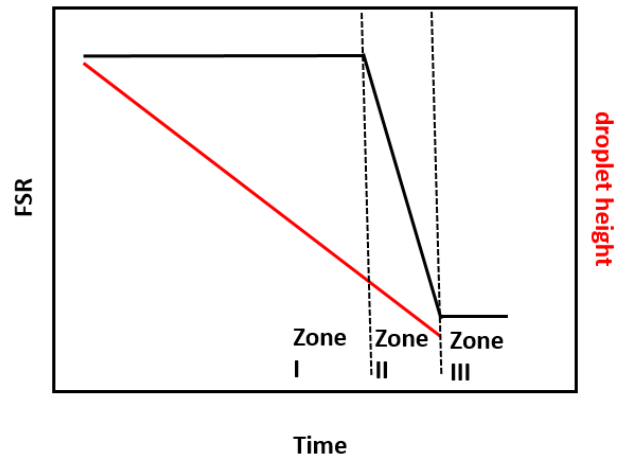

Fig. 1 (a) Experimental plot of the free spectral range and the height of the droplet against time during the drying of a $10 \mu \mathrm{L}$ sessile droplet at $\mathrm{T}=24{ }^{\circ} \mathrm{C}$. (b) Generic shape of the FSR and droplet height dynamics during a drying process.

Zone I (resp. zone III) corresponds to the situation where the water (resp. the air) acts like a semi-infinite upper cladding for the resonator. Zone II corresponds to the approach of the air/water interface when it is close enough of the resonator to influence the optical mode. We can deduce that the steeper the slope, the quicker the evaporation over time. We have performed a set of experiments at various temperatures: $18^{\circ} \mathrm{C}, 24^{\circ} \mathrm{C}$ and $30^{\circ} \mathrm{C}$ in order to modify the speed of evaporation and correlate it to modifications in the FSR dynamics, and for several volumes of droplet: $\mathrm{V}=5 \mu \mathrm{L}, 10 \mu \mathrm{L}, 20 \mu \mathrm{L}$ and $40 \mu \mathrm{L}$. Moreover, the experimental set up also includes a camera for a direct visualisation of the drying process, which allows a direct measurement of the rate of evaporation. This global study successfully verifies the correlation between the FSR dynamics and the speed of evaporation [4].

\section{References}

[1] D. Duval, H. Lhermite, C. Godet, N. Huby and B. Bêche, "Fabrication and optical characterization of sub-micronic waveguide structures on UV210 polymer", J. Opt. 12, 055501 (2010).

[2] D.G. Rabus, Integrated Ring Resonators, Optical Sciences Series (Springer, Berlin, 2007).

[3] L. Garnier, H. Lhermite, V. Vié, Q. Li, M. Berges, V. Cazin, H. Cormerais, J. Weiss, E. Gaviot and B. Bêche, "Photonic micro-resonators for steam evaporation dynamc sensing", Eur. Phys. J. Appl. Phys. 84, 10502 (2018).

[4] L. Garnier, H. Lhermite, V. Vié, H. Cormerais, O. Pin, Q. Liddell, and B. Bêche, "Dynamic monitoring of a drying water sessile droplet by resonant light probe", To be written, (2019). 